\title{
Significance and Strengthening Private Sector Engagement in the Management of Public Protected Areas: Experiences from Malawi
}

\author{
Njera D. ${ }^{1}$, Kafakoma R. ${ }^{2}$ \\ ${ }^{1}$ Department of Forestry, Faculty of Environmental Sciences, Mzuzu University, Mzuzu City, Malawi \\ ${ }^{2}$ Training Support for Partners, Lilongwe City, Malawi
}

Email address:

njera.d@mzuni.ac.mw (Njera D.)

\section{To cite this article:}

Njera D., Kafakoma R. Significance and Strengthening Private Sector Engagement in the Management of Public Protected Areas: Experiences from Malawi. International Journal of Natural Resource Ecology and Management. Vol. 2, No. 3, 2017 , pp. 47-52. doi: 10.11648/j.ijnrem.20170203.11

Received: January 31, 2017; Accepted: February 16, 2017; Published: April 13, 2017

\begin{abstract}
This paper presents the significance and strategies to strengthen private sector engagement in the management of public protected areas in Malawi. The study emanates from desk reviews of various relevant documents, stakeholder consultations and Malawi national Community Based Natural Resources Management forum discussions. In addition, focus group discussions with selected local communities surrounding conservation areas were conducted. Data analysis was conducted through content analysis and critical discourse analysis. Promotion of environmental education in protected areas, involvement of local communities in managing natural resources, Infrastructure development and conducting research studies on and in protected areas were found to be significant roles of private sector involvement in public protected areas. Unfavorable economic climate, weak regulation enforcement, poor monitoring mechanism of the activities undertaken by concessioners in managing the protected areas and poor dispute settlement mechanisms were seen to be the challenges. Lastly, enabling policy environment, long term tenure security, clear rights and responsibilities and selection of concessionaires by tender were found to be strategies for enhancing private sector participation in managing protected areas. A follow-up study should be conducted quantitatively in order to provide empirical evidence on the role and ways of strengthening private sector participation.
\end{abstract}

Keywords: Private Sector, Participation, Natural Resources Management, Protected Areas

\section{Introduction}

Since the Earth Summit of 1992 many countries in the world and the Southern Africa region, including Malawi have embraced a paradigm shift in the way natural resources are managed [1]. Literature $(2 ; 3)$ presents a variety of rationale for the paradigm shift from the traditional centralized decision making and planning to decentralized decision making and planning in natural resources management and utilization. The traditional approaches to management of public protected areas have been under question for a number of reasons. First, although they were devised to manage the natural resources, there has been adequate evidence that they failed to sustain resources they were designed to protect since over the years, there has been a significant steady increase in the degradation of natural resources in protected resources
[4]. Second, most central governments in sub-Saharan African African countries including Malawi rarely do have adequate financial resources to sustainably manage the natural resources on customary and public land [5]. Associated with this has been the inability by governments to enforce and implement relevant policies and laws due perhaps to technical and financial constraints, rampant corruption, and unnecessary bureaucratic controls. Third, the traditional centralized approaches were perceived to be at variance with the wider socio-political and economic transformation which has over the years taken place in the African region driven by democratic exigencies and good governance issues [5]. In addition, managing natural resources on public land has long been a challenge in 
developing countries where information is scarce, demands often high and the resources available to improve management often limited.

The alternative approach has been found to be the involvement of the private sector in managing the natural resources. This approach is seen by protagonists including governments, donors and non-governmental organisations (NGOs) as a viable option for improving rural livelihoods, securing environmental goals and promoting local economic growth. The premise underlying the involvement of the private sector in managing the public protected areas is that sustainable management of natural resources is most likely where the users, in this case, the private investors are able to manage and extract benefits from the resources.

The paradigm shift by most governments in sub-Saharan Africa including the Government of Malawi has entailed increased recognition of the important role of the various players or stakeholders such as communities, private sector organizations and others have in the management of the natural resources. The fundamental goal in the shift is to make an effective transition from traditional resource policing methods to working with communities and the private sector $[2,3,4]$. The aim is to increase local communities' and private sector's responsibilities and rights over the management of their resource base while increasing their incomes and livelihood support from the same resources [5]. Malawi has made tremendous efforts in making broadbased reforms and institutional restructuring to ensure effective participation of the various stakeholders in the management of the natural resources.

In Malawi, the private sector has invested in such areas as advocating legalization of protected areas, ecotourism, conducting ecological research and monitoring, environmental education, infrastructure development, lawenforcement and re-introduction and management of game. However, the degree of private sector involvement has been limited to a few stakeholders, those directly or indirectly affected by wildlife, those deriving benefits from wildlife such as tourism companies, and those with vested interests in wildlife conservation such as conservation organizations and "green companies". Private investments have focused on specific individual protected areas according to the particular interest of the private investor [6]. Even though the government has put in place institutional arrangements, incentives and mechanisms to attract private investments and ensure that investments benefit protected areas, these are still in their infancy. While there is high potential for private sector investments to support protected areas, most private investors are trapped in a dilemma on how they can invest in protected areas [7]. This paper seeks to present some key strategies for effective and sustainable engagement of the private sector in the management of public protected areas in Malawi. The paper presents potential benefits of engaging the private sector in the management of the public protected areas based of empirical evidence, followed by challenges faced, and recommendations to attract private sector participation.

\section{Methodology}

The study emanates from desk reviews of various relevant documents, stakeholder consultations and Malawi national Community Based Natural Resources Management forum discussions. In addition, focus group discussions with selected local communities surrounding conservation areas such as forests and national parks were conducted. Furthermore, selected CBNRM sites in the fisheries, forestry, water and wildlife sectors were visited and semi-structured interviews with various stakeholders were conducted. Data analysis was conducted through content analysis and critical discourse analysis as advanced by Mack [8].

\section{Results and Discussion}

\subsection{Relevance of Private Sector Participation in Managing Public Protected Areas}

Results showed that the private sector had been involved in managing protected areas in Malawi through various ways. The major activities that the private sector has been undertaking as a way of managing the public protected areas include the following:

\subsubsection{Promotion of Environmental Education in Protected Areas}

The private sector has been involved in the promotion of environmental education on natural resources management in protected areas. African Parks Limited is one such private sector organization that has been very active in environmental education around the Majete Wildlife Reserve whose boundary straddles in Chikhwawa, Blantyre, Mwanza and Neno districts.

\subsubsection{Promoting Participation of Local Communities in Managing Natural Resources}

Apart from a social responsibility for communities around protected areas, the private sector was involved in the provision of the necessary opportunity for local communities to participate in natural resources management. For example, private companies and other stakeholders involved in natural resources management in protected areas encouraged local communities to undertake entrepreneurship activities within or on the periphery of the protected areas. Benefits from such activities provided strong incentives and robust motivation for local community participation to take part in managing natural resources in protected areas. For instance, the African Parks Limited (Majete) had established a community centre within the national park which was managed by the local communities surrounding the Majete Wildlife Reserve. This was one of the strategies that encouraged members of local communities to establish co-ownership of the natural resources, e.g. game and forest resources in the reserve which eventually provided the impetus for local participation in managing the protected areas. In addition, African Parks (Majete) had mobilized local communities into 19 Community Based Organizations (CBOs), which in turn, 
formed and institutionalized the Majete Wildlife Reserve Community Association (MWRCA). This appeared to be of significant importance in strengthening local democratic governance of natural resources in most parts of the country [9].

\subsubsection{Infrastructure Development}

It was also observed that another major component of private sector investments has been the development of infrastructure in and around the protected areas. These include provision of utilities such as piped water and electricity, school blocks, student hostels and visitor centers, maintenance of trails and guides and construction and maintenance of road networks and fences [10].For example, African Parks (Majete) has improved road network in Majete Wildlife Reserve from $18 \mathrm{~km}$ to $300 \mathrm{~km}$ from 2003 to date. These facilities show the importance of social responsibility undertaken by the private investors in managing the public protected areas. Such facilities are common in national parks, wildlife reserves and forest reserves which also promote tourism.

\subsubsection{Promoting Better and Sustainable Management of Protected Areas}

The involvement of the private sector in managing the public protected areas is further promoted against a premise that the state's dwindling financial resources which cannot effectively maintain and manage the protected areas. It is estimated that protected areas in developing countries receive an average of less than 30 percent of the funding estimated to be needed for basic conservation management [11] (http://rru.worldbank.org/PublicPolicyJournal). Thus, alternative mechanisms of financing protected areas or encouraging private investments in protected areas are continually being sought. In the case of the Department of Wildlife and National Parks, the private sector has assisted the government in re-introducing and managing game in protected areas. For example, in 1987 Malawi was reported to have about 25 black rhinos (Dicerosbiconis), but in 1990 the species was officially declared extinct when Malawi's last black rhino was poached in Mwabvi Game Reserve [12] in [13]. In the Forestry Department, reports indicate that there has been a significant increase in forest cover within the concession area that is being managed by RAIPLY (Malawi) Limited [14]). This emphasizes the need for the promotion of private sector participation in natural resources management in public protected areas.

In addition, the private sector has a central role to play in supplementing the government in its efforts to effectively and sustainably manage protected areas [15]. Much as the government could have wished to manage the natural resources in protected areas as its prerogative through the various ministries and departments [16], it rarely possesses enough personnel or financial resources to adequately enforce the relevant policies and acts [1. 17]. In essence, the lack of adequate resources by government has been a significant contributing factor for increased rate of natural resources' decline in this country. In this regard, there is a wide recognition that the state's dwindling financial resources cannot effectively maintain and manage protected areas. Thus, alternative mechanisms of financing management and governance of protected areas such as encouraging private investments in protected areas are continually being sought.

\subsubsection{Conducting Research Studies on and in Protected Areas}

The privatesector is also involved in conducting both short-term and long term ecological and socio-economic studies within and on the periphery of protected areas. For instance, according to [9], the Wildlife and Environmental Society of Malawi carried out various research activities particularly on animal population and migration, efficacy of tourism industry in national parks and game reserves and on plant and animal ecology. The society also undertook management activities in national parks and forest reserves. Similarly, individual members and local community groups have also been involved in carrying out research studies especially in areas of ornithological (birdlife) studies and vegetation surveys in national parks and forest reserves. Such studies are aimed at promoting sustainable and effective management and utilization of natural resources within the public conservancies.

\subsection{National Policies Promoting Private Sector Participation Managing Protected Areas}

During the study, it was noted that the Government of Malawi's policies for Community Based Natural Resources (CBNRM) most clearly exemplified in the forest, wildlife and national parks and fisheries sectors, are based on a transfer of rights and responsibilities from government to user institutions, formalized through legally binding resource management agreements. In addition, the government has developed various other policy and legal frameworks supporting and promoting the participation of various stakeholders in the management of natural resources. Some of such frameworks include the Malawi Growth and Development Strategy II [16], a medium term development agenda for the government, and the Public Private Partnership (PPP) framework which is promoting and strengthening private sector participation in infrastructure investment. These policy and legislative frameworks are in support of the private sector participation in managing public protected areas. For instance, the National Environmental Policy promotes the involvement of the private sector, Nongovernmental Organizations (NGOs) and local communities in the management, conservation and sustainable utilization of natural resources located in public protected areas. Further, the Malawi National Forest Policy (1996) and the Forest Act of 1997 aim to provide an enabling framework for promoting participation of communities and the private sector in forest conservation and management. As one of its key strategies, the National Forest Programme promotes involvement of private sector in the management of the public protected areas, exemplified by management of forests at Chikangawa by RAIPLY Timber Company. 


\subsection{Challenges Affecting Private Sector Participation in Managing Public Protected Areas}

The study noted the following drawbacks to the enhancement of private sector participation in managing the public protected areas: Unfavorable economic climate such as scarcity of foreign exchange currencies. This was acute in 2012 to 2014 financial years largely due to the worsening trend of the national economy that was prevailing in the country. Another challenge was weak regulation enforcement by the contracting authority such as the government line ministries or departments. In this regard, the contracting authority might have low capacity in enforcing laws that aim to ensure that the private sector involvement in managing the public protected areas complies with the provisions of the concession agreement. Poor monitoring mechanism of the activities undertaken by concessioners in the course of managing the protected areas and poor dispute settlement mechanisms which affects the performance of the private company were also seen as some of the drawbacks. Another drawback was related to inconsistencies in policy implementation: An example in this relates to tourism sector which requires support of the ministry responsible for public works for timely and regular road maintenance leading to and in the protected areas such as national parks, which can facilitate easy access to the tourist sites. There seem to be no coordination between the two ministries looking at the poor condition of most roads leading to and in the protected areas. Lastly, since the 1990s, when the government decided to promote stakeholder participation in natural resource management, the influx of private sector organizations to the natural resource management sector has been very low. Few private sector organizations are involved in ecotourism and usually have limited interest to promote community participation. Also, very limited private sector organizations are involved or have entered in co-management agreements with the local communities to manage a particular resource even though the policy and legal frameworks in the country are supportive of such efforts. Private sector organizations focus on timber utilization for making immediate profits since natural resource management takes time to yield such profits.

\subsection{Enhancing Private Sector Investment in Managing Public Protected Areas}

The study further showed that the private sector organisations have their interest in business and therefore conditions need to be attractive to stimulate their interest to invest in the management of protected areas such as game parks. Some of the conditions proposed by the respondents during the study include enabling policy environment, long term tenure security, clear rights and responsibilities and selection of concessionaires by tender. These have been discussed in this study.

\subsubsection{Provision of an Enabling Policy Implementation Environment}

An enabling policy environment that provides freedom for investment encourages private sector investments. Similarly, political stability is essential for encouraging long term private investments in protected areas. Since 1994, the government of Malawi has carried out a number of policy reforms. The Malawi Growth and Development Strategy (MGDS II), has nine priorities which recognize the important roles of the private in spurring economic development through increased investments especially those directed towards improving and expanding infrastructure. In line with the MGDS, the government also developed the Public Private Partnership Policy and Act (2011) in order to strengthen the investment climate in the country through improving the business environment to attract more private sector organization and participation in the economic development of the country [16].

To attract private investment, Mauambeta [13] reports that the Government of Malawi has put in place a number of investment incentives. Some of these include; free access to foreign exchange; no license requirements for imports; full remittance of dividends; corporate tax rate of $35 \%$;generous tax allowances including $40 \%$ allowance on new buildings and machinery, additional $15 \%$ allowance for investments in designated areas; up to $20 \%$ allowance for used buildings and machinery; $50 \%$ allowance for qualifying training costs $; 100 \%$ deduction for manufacturing company operating expenses during the first 18 months and transport tax allowance equal to $25 \%$ of international transport costs. However, there are no specific incentives that promote private investments in protected areas. This is evidenced by complaints of Tourism Operators in Malawi who indicate that "Malawi is one of the most overtaxed tourism industries in the SADC region and as a result one of the least successful". Unlike other countries, there is no incentivisation and no tax breaks here in Malawi [13].

\subsubsection{Ensuring Long Term Tenure Security for Their Investments}

Most private companies believe that they can only invest in protected areas if there is clear long term tenure security to allow for full recovery of investment costs on capital and to generate some reasonable profit margins [16]. The Government of Malawi is aware of this as exemplified from the first ever concession agreement signed between the Government and the African Parks (Majete) Limited to manage Majete Wildlife Reserve for 25 years with a possible extension [17].

\subsubsection{Defining Clear Rights and Responsibilities for Natural Resources Governance}

Linked to tenure security is the question of rights and responsibilities of the stakeholders within the private sector. The clarification of rights and responsibilities in concession agreements is very important if the private sector is to invest in protected areas. Tenure rights to the natural resources contribute towards the effectiveness and sustainability of the private sector in managing such resources [18]. This implies that for the private sector to actively participate in management of protected areas, it is necessary for resource 
ownership, control and land tenure questions to be clearly defined. Confidence in tenure rights on natural resources are prerequisite for longer natural resources management planning horizons by the private sector [19], consequently sustains the management of the public protected areas. For example, African Parks (Majete) Limited has the right and responsibility to manage the protected area in a sustainable manner and make its own decisions on the utilization of the protected area and its resources suffice it to say that African Parks (Majete) has been given management rights while the land and wildlife therein belong to the government. Clear rights and responsibilities give the investor commitment, trust and confidence to fully invest in a business [20]. As of August 2003, African Parks (Majete) Limited had already started to fully invest in the reserve.

\subsubsection{Strengthening Selection of Concessionaires by Tender}

Tender processes should be used at all times in selecting organizations to run public assets through concessions. Monopoly power creeps in if the tendering process is not done. The tendency is that if one particular private organization is favored it tends to relax, resulting in failure to fulfill terms and conditions stipulated in the concession agreement. Therefore, the award of concessions to run protected areas should be done through tendering process.

\section{Conclusion}

Private sector participation is crucial for the management of public protected areas. Promotion of environmental education in protected areas, involvement of local communities in managing natural resources, Infrastructure development and conducting research studies on and in protected areas were found to be significant roles of private sector involvement in public protected areas. Unfavourable economic climate, weak regulation enforcement, Poor monitoring mechanism of the activities undertaken by concessioners in managing the protected areas and poor dispute settlement mechanisms were seen to be the challenges. Lastly, enabling policy environment, long term tenure security, clear rights and responsibilities and selection of concessionaires by tender were found to be strategies for enhancing private sector participation in managing protected areas. A follow-up study should be conducted quantitatively in order to provide empirical evidence on the role and ways of strengthening private sector participation.

\section{References}

[1] Njaya, F. (2007). Governance Challenges for the Implementation of Fisheries Co-Management: Experiences from Malawi. International Journal of the Commons Vol 1, no 1 October 2007, Igitur, Utrecht Publishing and Archiving Services for IASC pp. 137-153.

[2] Huntjens, L., Lebel, L., Pahl-Wostl, C., Camkin, J., Schulze,
R. and Kranz, N. (2012). Institutional design propositions for the governance of adaptation to climate change in the water sector. Global Environmental Change 22 (2012) pp 67-81.

[3] Cinner, J. E., Basurto, X., Fidelman, P., Kuange, J., Lahari, R. and Mukminin, A. (2011). Institutional designs of customary fisheries management arrangement in Indonesia. Papua New Guinea and Mexico.

[4] COMPASS (2005). Decentralisation and forestry. A review of progress, challenges and opportunities for CBNRM in the forestry sector. Occasional paper 8.Community Partnerships for Sustainable Resource Management.

[5] Eliasi B, Aubin S, Sunga I (2009). Enhancing smallholder farmers policy engagement through greater involvement of farmer organisations in policy processes.' Paper presented at the IDASA Economic governance programme conference on 'Governance and small scale agriculture in Southern Africa'. Available http://www.sacau.org/hosting/sacau/SacauWeb.nsf/Paper_IDAS A\%2.Accessed on 24/08/2015.

[6] Mack, N., Woodsong, C. Macqueen, K. Guest Greg and Namey E. (2005). Qualitative Research Methods: A data collector's Field Guide. Family Health International

[7] Government of Malawi (2001). National Fisheries and Aquaculture Policy. Ministry of Natural Resources and Environmental Affairs. Department of Fisheries. Lilongwe. Malawi.

[8] Government of Malawi. (2009). The Malawi Growth and Development Strategy. From poverty to prosperity, 2006 to 2009.Revised Edition. Ministry of Economic Planning and Development. Lilongwe. Malawi.

[9] Government of Malawi. (2011). Malawi Agricultural Sector Wide Approach. A prioritised and harmonised Agricultural Development Agenda: 2011-2015. Ministry of Agriculture and Food Security. Lilongwe. Malawi.

[10] Saporiti, N. (2004) Managing National Parks. Public Sector Policy for the Private Sector.http://rru.worldbank.org/PublicPolicyJournal.

[11] Mauambeta, D. (2003). Private Investments to Support Protected Areas: Experiences from Malawi. Vth World Parks Congress: Sustainable Finance Stream, Durban, South Africa.

[12] Maumbeta, D and Kafakoma, R. (2010). Study Report on CBNRM Stocktaking in Malawi. Coordinating Unit for the Rehabilitation of the Environment, Blantyre, Malawi.

[13] Government of Malawi (2011a). Malawi Growth and Development Strategy. Lilongwe, Malawi.

[14] Government of Malawi (2001). National Forestry Programme. Priorities for Improving Forestry and Livelihoods.Department of Forestry. Ministry of Forestry, Natural Resources and Environment. Lilongwe, Malawi.

[15] Government of Malawi (2011). Public Private Partnership Policy and Act.The Secretariat, Public Private Partnership Commissions, Lilongwe, Malawi.

[16] Kaarhus, R and Nyirenda, R. (2006). Decentralisation in the agricultural sector in Malawi. Policies, processes and community linkages. Noragric Report No. 32.Norwegian University of Life Sciences. Norway. 
[17] Kaarhus, R., Jorgensen, I., Kamoto, J., Mumba, R., Sikwese, M., and Ferrar, S., (2003). Nkhalango.A Social Forestry Model. Experiences from Blantyre City Fuelwood Project in Southern Malawi.Agricultural University of Norway.

[18] Maumbeta, D., Chitedze, D. and Mumba, R. (2010). Status of forests and tree management in Malawi. A position paper prepared for the coordination union for rehabilitation of the environment (cure).

[19] Wilson and Morgan (2003) Agreement between the
Government of Malawi (Ministry Of Tourism, Parks and Wildlife) and African Parks Management and Finance Company (PTY) Limited and the African Parks (Majete) Limited concerning the Management of Majete Wildlife Reserve. Blantyre, Malawi.

[20] Mapila, M. and Haankuku, C. (2009). To march or not to march? Understanding the potential role of lobbying in positively influencing agricultural policy outcomes for Smallholder Farmers in developing countries. Afr. Growth Agenda, January-March: pp. 10-12. 